five tons. Recent archæological discovery, notably in Yorkshire, at Colchester and most recently at Lincoln, have made familiar the kiln and mode of firing employed by the Romano-British potter; but as a rule the conditions of discovery have precluded preservation for general inspection. The kiln now on view at the Science Museum is the only example of the period exhibited in Great Britain.

\section{Exhibition of Kinematography}

THE fourth Exhibition of Kinematography, arranged by the Royal Photographic Society, was opened at the Society's premises, 35 Russell Square, London, on November 28 and will remain open until December 19. A large selection of still pictures illustrates the ever-widening scope of kinematography, and includes examples of the work of many producing companies and amateur societies, and of films-scientific, instructional and for purposes of entertainment and publicity. Much recent apparatus, standard and sub. standard, is on view, this section including exhibits by most of the leading manufacturers. A Vinten gyroscopic tripod for $16-\mathrm{mm}$. work is particularly worthy of note. Stock manufacturers are also to the fore. Kodachrome is being exhibited in $16-\mathrm{mm}$. and $8-\mathrm{mm}$. sizes, the smaller size being not yet on the market in Great Britain. On this stand, too, Messrs. Kodak show samples of $16 \cdot \mathrm{mm}$. work with Pola screens, Messrs. Ilford have staged an exhibit with photographs illustrating the manufacture and testing of Cine products. Examples of their various products, including Dufaycolor, are on view. A comprehensive programme of lectures has been arranged on subjects varying from sound recording to the making of cartoon films. No charge is made for admission to the Exhibition, to the meetings, or for reserving seats.

\section{Dr. E. Bausch and the Optical Industry of America}

The American Society of Mechanical Engineers made its annual awards for distinguished service in engineering and science, and "for great and unique acts of an engineering nature that have accomplished a great and timely benefit to the public" on December 1 to Dr. Edward Bausch and Mr. Henry Ford, when Dr. Bausch received the A.S.M.E. Medal and Mr. Ford the Holley Medal, the former established in 1920 and the latter in 1923. The A.S.M.E. Medal is awarded once a year, "and that only for inventions and improvements of great merit in the technical and public sense". Among the previous recipients have been H. G. Carlson, Dr. Robert A. Millikan, Dr. Ambrose Swasey, and other distinguished contributors to the progress of engineering. In his long and notable career, which began with the construction of his first microscope in 1872, Dr. Bausch has been a constant contributor to engineering progress. At eighty-three years of age, he is still at work, and recently, with other members of the Bausch and Lomb Optical Co., has designed the contour measuring projector. This new instrument is proving itself a valuable inspection device in many types of industry. It is both a microscope and a projection apparatus of the highest quality and great accuracy with which a highly magnified profile of such parts as screw threads, gears, dies, gauges and shapers may be thrown upon a screen or chart for study and comparison.

Dr. BAUSCH entered his company's service sixty. two years ago, immediately upon leaving Cornell University. As assistant to his father, John J. Bausch, he is credited with the great expansion of the industry in the United States through the introduction of new technical methods and machine processes to compete with the cheaper hand labour of Europe. Dr. Bausch has for many years been a fellow of the Royal Microseopical Society, and has a wide acquaintance with workers in this field both in Europe and the United States. Not content with his own efforts in building up the optical industry, Dr. Bausch has been conscious of the necessity of educational work to perpetuate his labours. This explains his interest in the establishment of the Institute of Optics, as a part of the Physics Department of the University of Rochester, and the construction of the Bausch and Lomb Physies Building at the University in honour of his father and Captain Henry Lomb, founders of the Bausch and Lomb Optical Co.

\section{Research on Atmospheric Pollution}

THIRTY.THREe representatives of local authorities and other organizations co-operating with the Department of Scientific and Industrial Research met at the Fuel Research Station of the Department at East Greenwich on November 30 to discuss the investigation of atmospheric pollution. Dr. G. M. B. Dobson, chairman of the Atmospheric Pollution Research Committee, presented a report on the progress of the investigations carried out under the auspices of the Committee. The Conference noted especially that arrangements are well in hand for the intensive survey of pollution in and around Leicester. After the meeting, the representatives were shown the work of interest to them which is in progress at the Fuel Research Station. Broadly speaking, there are two fundamental and closely related factors involved in the reduction of atmospheric pollution by coal burning-the nature of the fuel and the appliance in which it is burned. The former of these leads to the selection from the varieties available of fuel most suitable for a given purpose. The preparation of coal for the market, by cleaning and grading, assists materially in the reduction of pollution; the cleaning yields a coal of lower ash content, thus decreasing the potential emission of ash in the form of grit, while grading the coal according to size reduces the content of small particles which may be blown from the fuel bed by the draught. The aim in coal-burning appliances is towards greater control over the combustion. This is obtained by uniform air distribution to the fuel and the regulation of air supply, thereby promoting efficient combustion and a reduction of the unburned products passing into the atmosphere. In the domestic field attention has been devoted mainly to the production from coal of a 
free-burning smokeless fuel, by removing the greater part of the volatile matter which is responsible for most of the smoke nuisance. Appliances have been designed for the burning of such smokeless fuel. Efforts are also being made to test and modify domestic appliances so that raw coal may be burned more efficiently and with a substantial reduction of pollution.

\section{Domestic Cokes}

TrE Institute of Fuel and the Manchester Associa. tion of Gas Engineers held a symposium on domestic cokes in Manchester on November 18. Arnold Marsh examined the question from the point of view of smoke reduction and, discussing the scope of the different smokeless fuels, concluded that all forms of coke would be required. E. C. Evans, on the other hand, fears that an increase in the use of oven coke for domestic purposes would be disadvantageous to the economic production of pig iron. Even now there is a shortage of suitable blast furnace coke. H. J. Hodsman, discussing the relation between the properties of a coke and its behaviour in the grate, emphasized that shallow modern grates cannot be justified on the ground of efficiency on consuming any fuel-whether raw coal or coke. The deeper fuel bed is more rational and this is being recognized by the consumer, for E. W. L. Nicol pointed out that 70,000 such grates convenient for burning coke are sold annually. A. Blackie described two suitable designs of grate which have proved satisfactory. Emphasis was laid on the possibility of activating high-temperature cokes with soda. Prof. J. W. Cobb described how in 1925 it was observed that the reactivity of coke to carbon dioxide is enormously increased by treatment with soda. The chance of industrial use of this has been increased by P. J. Askey's observations that in presence of lime, the addition of even so little as 0.5 per cent sodium carbonate to a coke may produce an adequate increase in the reactivity. R. A. Mott described experiments made with H. H. Thomas in Liverpool Gas Works on alkali activation made under coke oven conditions. These leave little doubt that high-temperature cokes can be made to burn more actively as a result of alkali treatment; but the economic future of the process will depend on other factors. Many existing gas works would find it difficult to introduce a process of pretreating coal into their routine.

\section{Acquisitions at the British Museum (Natural History)}

Mr. W. FALConer has recently presented to the Department of Zoology males and females of eightyfour British species of spiders all new to the collection. This valuable gift makes the collection of British spiders in the Museum almost complete. Another interesting accession comprises nine spiders' webs mounted between sheets of glass, the webs being made visible by a black background and the judicious application of baby powder. Prof. G. H. F. Nuttall has presented to the Department of Entomology the whole of the material upon which he based his well-known studies on the human louse. His results, published in Parasitology (1917-30), include a very full summary of its relation to typhus, relapsing and trench fever, and other diseases which it carries, and a detailed account of methods of combating lousiness. Among other things Prof. Nuttall dernonstrated that the head louse and body louse are not distinct species, but only varieties, possibly showing slight biological differences, of a single species. Recent accessions to the Department of Geology include an extensive series of petrified cones and wood of Araucarian conifers from Patagonia, collected and presented by Dr. F. Mansfield. Many of the specimens have been cut and polished, and the preservation, in chalcedony of various colours, is very good. These fossils were found in the Cerro Alto and Cerro Cuadrado region of Santa Cruz, which has been described as one of the world's most marvellous petrified forests ; the material has not yet been fully studied, and the geological age is still uncertain, though it is probably at least as old as early Tertiary. Several hundred invertebrates, mainly corals, from the Palæozoic of Germany and Bohemia, have been collected and presented by Dr. Stanley Smith. The Mineral Department has received by exchange with the Mineralogical Museum, Moscow, an interesting series of specimens from Kola Peninsula and various localities in Central Asia. Lord Ilchester has given a series of pebbles from carefully defined points on the Chesil Beach, which is probably the most remarkable bank of shingle in the world.

\section{Exhibit of the Biology of Water-Supply}

A NEw exhibit which has been installed in the Central Hall of the British Museum (Natural History) illustrating the biology of water-supply shows, more fully than its predecessor, the influence of plants and animals on the purification of water for human use. It shows how river-water is purified by storage in reservoirs, followed by filtration through sand. Some of the organisms living in the water of a river find the conditions in waterworks more favourable, and multiply greatly. Thus great swarms of minute plants, and the animals that feed on them, arise in reservoirs. This is sometimes to the advantage of the water engineer, and sometimes greatly to his disadvantage. The beneficial effects include oxygenation of the water by the plants, and the formation of a natural filtering film, more efficient than any artificial film, in stopping the passage of bacteria. This living film, which consists chiefly of microseopic plants, forms on the surface of the sand and gravel of the filter-bed. Trouble arises if the living things in the reservoirs become so numerous as to choke the filters, or are of such a kind as to give an unpleasant flavour to the water. These points are illustrated by specimens, photographs and diagrams. History has shown that, without sand-filtration, mains and supply-pipes are apt to become seriously blocked with animal growths. This is illustrated in the exhibit, which also shows how the excessive growth of microscopic plants can be checked, how wells and springs come to give good or bad water, how sudden and severe outbreaks of 